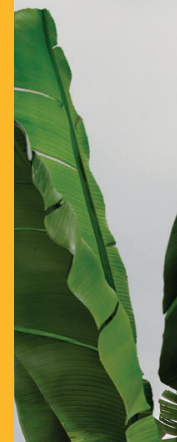

The Journal

\section{of the}

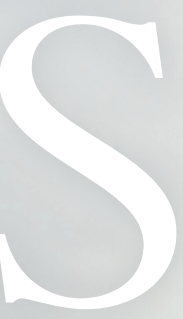

VOLUME 128 No.3 SEPTEMBER 2019

THE POLYNESIAN SOCIETY THE UNIVERSITY OF AUCKLAND NEW ZEALAND

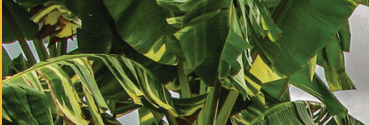

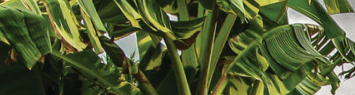

$3 x^{3}$

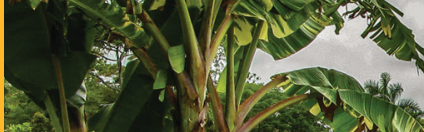

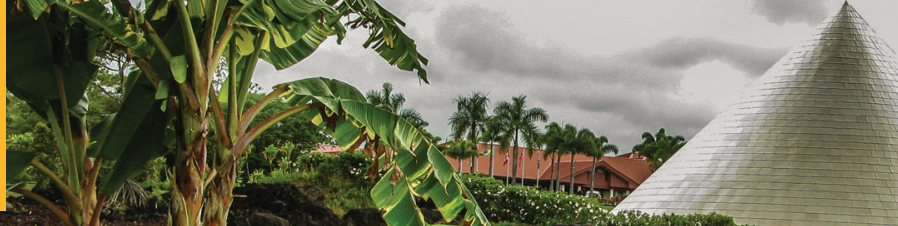

(6)

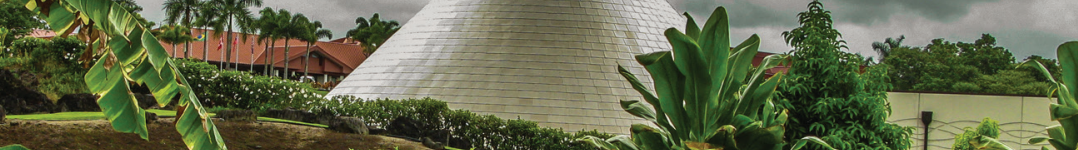

$1012(12)=0$

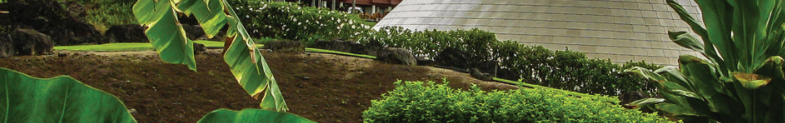

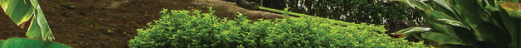

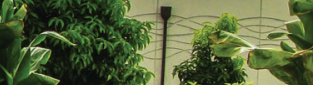

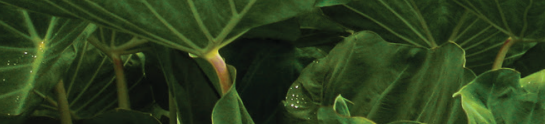




\title{
LETTERS TO A MĀORI PROPHET: LIVING WITH ATUA IN MID-NINETEENTH-CENTURY TARANAKI (NEW ZEALAND)
}

\author{
JEFFREY SISSONS \\ Victoria University of Wellington
}

\begin{abstract}
The focus of this article is a remarkable collection of letters written in the late 1850s to the Māori prophet Tamati Te Ito Ngāmoke of Taranaki (New Zealand). Building on a translation of and introduction to these letters by Penelope Goode, I focus on letters that are concerned with tapu 'sacredness' in relation to sorcery and seasonal activities and argue that they provide a unique insight into tapu as an enduring historical condition in relation to which people were required to develop a new mode of collective engagement or correspondence. I conclude with some reflections on the concept of "correspondence" as recently developed by Tim Ingold and consider how, in light of his argument, the Kaingārara letters can be understood as mode of correspondence in a double sense: both as writing and as ontological becoming.
\end{abstract}

Keywords: tapu, Māori prophets, human correspondence, Deleuzian anthropology, intense centre, Taranaki (New Zealand)

In December 1859, Rewi Maniapoto, a powerful Waikato chief and leading proponent of the emergent Māori King movement, wrote to the leaders of a rival sovereignty movement in Taranaki:

E hoa ma, whakamutua ta koutou mahi kikokiko. Kaua e tohe. Whakamutu rawatea.

Friends, cease your work of expelling malevolent spirits. Don't continue with it. Cease completely. (Goode 2001: 140, my revised translation)

The "work" to which Maniapoto was referring included ceremonies orchestrated by Taranaki's first prophet, Tamati Te Ito Ngāmoke, that were intended to free the district from the presence of malevolent ancestral spirits (atua kikokiko). These ceremonies, which included the burning of carvings, clothing and tapu 'sacred' remains from wähi tapu 'sacred groves', had recently been part of a collective effort by Te Ito's Kaingārara movement to unite the Taranaki tribes in opposition to land sales and to establish an independent polity that included an indigenous school and court system 
(Sissons 2016, forthcoming). But it had been more than two years since the prophet had staged one of his fires. Since January 1858, he had been serving as the visionary advisor to Wiremu Kinngi Te Rangitāke, paramount chief of the northern Taranaki tribe, Te Āti Awa (Riemenschneider 1858: 328; Nelson Examiner and New Zealand Chronicle, 23 January 1861, p. 3). In this role, he had been a leader in the military defeat of Ihaia Te Kirikūmara, a rival to Te Rangitāke who had offered land at Waitara to the Government, and he was now supporting Te Rangitāke in his efforts to unite Te Āti Awa against land sales (Whiteley to McLean, 25 March 1858; Scholefield 1960: 618-22). For most of this period, Te Ito had been residing at Waitara in a kāinga 'village' named Te Whānga and, from here, he participated in an extensive written correspondence with his followers living thoughout the Taranaki district, guiding them in their relationships with atua kikokiko and their associated tapu. Both Te Ito's earlier fire ceremonies and this written correspondence would have been of concern to Rewi Maniapoto because, as centralising, pan-tribal activities, they challenged the ambitions of his King movement to extend its influence into Taranaki.

Rewi Maniapoto's letter is included among 52 letters written to Tamati Te Ito between 1857 and 1863 that were first identified and translated in a groundbreaking MA thesis by Penelope Goode (2001). Goode's thesis was supervised at the University of Canterbury by Lyndsay Head, whose own path-breaking scholarship on Te Ito's prophetic successor, Te Ua Haumene, has contributed significantly to my understanding of the nature and origins of prophetic movements in Taranaki. In this article, I seek to extend their work and argue that the Kaingārara letters provide us with a unique insight into tapu as an enduring historical condition in relation to which people were required to develop new forms of collective engagement or correspondence. I begin with a reconsideration of tapu in nineteenthcentury Māori society and propose that it should be understood not as a quasi-legal phenomenon underpinning a hierarchical order but, instead, as a shifting historical condition that necessarily accompanied life lived with atua. Next, turning to the Kaingārara correspondence, I argue that through their letters Te Ito and his followers were reaffirming the enduring nature of tapu through a new mode of collective engagement with it, one in which Te Ito assumed the role of local tohunga 'priest, shaman, healer' now writ large at a pan-tribal level. I conclude with some reflections on the concept of "correspondence" as recently developed by Tim Ingold (2018) and consider how, in light of his argument, the Kaingārara letters can be understood as mode of correspondence in a double sense: both as writing and as ontological becoming. 


\section{LIVING WITH ATUA}

There is now a clear consensus in the anthropological literature that for preChristian Māori a state of tapu arose from active relationships with beings termed atua (Best 1924, vol. 1: 251; Hanson and Hanson 1983: 50-52; Salmond 1989: 74-75; Sissons 2015: 135-41, 2016: 60-62). The term "atua" is often translated as "god", but this post-missionary gloss is, at best, quite misleading. Although Christian missionaries chose the capitalised term "Atua" to refer to their "God", Māori atua were certainly not "gods" in the Christian or classical European sense. Pre-Christian atua were either distant ancestors, from whom humans and non-humans (forests, birds, fish, crops, winds, etc.) were descended, or they were beings that participated more directly in social life as the embodiments of ancestral spirits controllable by tohunga.

Ritual techniques for controlling or directing the power of the latter atua were developed and used by tohunga to ensure that people could safely and productively dwell in their world. These atua could empower leaders but, if offended, they might also kill them, assuming the form of lizards (ngārara) and devouring their internal organs. The earliest recorded instance of such a fate was the death of the Bay of Islands chief Ruatara soon after his return to New Zealand bringing the first Christian missionaries in 1814. When Ruatara lay sick and in a tapu state, isolated from the village community, he was visited by two of the missionary party who, by thus violating the relationship of tapu, offended his atua. One of the visitors, John Nicholas, later wrote that people had told him that the atua had, as a consequence, "fixed himself in the stomach of the chief" (1817, vol. 1: 166).

Tapu was not a transcendent order imposed by transcendent gods. Relationships between chiefs, such as Ruatara, and their vengeful, unpredictable atua were ongoing daily concerns as states of tapu were produced, controlled and negotiated by tohunga. And yet, it was a governmental, legalistic understanding of tapu that came to predominate in colonial and early ethnographic explanations of the concept. The ethnographer Elsdon Best wrote, for example: "To put the matter briefly, it may be said that tapu means prohibition, a multiplication of 'Thou shalt not'. These may be termed the laws of the gods, and they must not be infringed" (1924, vol. 1: 251). Writing in the $1850 \mathrm{~s}$, around the time of the events to be discussed in this article, the Whanganui missionary Richard Taylor defined tapu as "a religious observance, established for political purposes" (1855: 55), and Judge F.D. Fenton later concurred, describing it as "an institution that has had the force of law among the people ... by it a chief or ariki was able to exercise a very great influence over his people" (AJHR 1860 F-3 no. 3: 90). 
A moral, governmental view of tapu was also widely assumed in accounts of the rapid collapse of tapu as an institution after conversions to Christianity. Richard Taylor, this time in full poetic voice, wrote that the introduction of Christianity had caused the political system to completely collapse and, "like the chaff of the summer's thrashing floor, the wind of God's word has swept it away" (1855: 64). In a more prosaic, functionalist tone, Prytz-Johansen pointed out that the demise of tapu required new forms of colonial governance: "When the tapu institution disappears, fields, forests, and fishing grounds lie open to arbitrariness and a new protection is to be built up by the law as understood by Europeans" (1954: 197).

However, as an enduring condition that arose from an active relationship between atua and people, tapu did not simply come crashing down with mass conversions to Christianity in the 1840 s - nor did atua suddenly cease to exist. Rather, the relationships changed, becoming problematised in new ways as they became, in some contexts, increasingly hostile. Atua, once amenable to knowledgeable control by tohunga with karakia 'chants', now came to be regarded as uncontrolled, malevolent spirits (termed "atua kikokiko" in Taranaki and Waikato) that were causing widespread sickness and death. Atua, such as the one which attacked the Bay of Islands chief Ruatara, had often assumed the form of ngärara-lizards, reptiles and other "creepy-crawlies" - and this was reflected in the name Kai-ngārara, (lit.) 'reptile-eaters', chosen by the followers of Tamati Te Ito; the name referenced the movement's determination to combat a malevolent multitude of atua, turned atua kikokiko, and their contagious, dangerous tapu. Goldie succinctly equates atua, ngārara and kikokiko in the following comment: "Sickness made a person tapu because of the atua or demon, ngarara or lizard, kikokiko or ancestral ghost, entering into the body of the afflicted" (1904: 4).

A top-down, governmental view of tapu misses the point that this is a condition that continually emerges through interaction with atua, both benign and malevolent. It is, to use Deleuze and Guattari's (1987) term, a mistaken "arborescent" view that assumes society to be ordered by branching categories and sub-categories, reproducing the perspective of a colonial state. Instead, Māori society was, in Pierre Clastres's sense, a "society against the state" in which tapu, derived from associations with atua, was the precondition for a "rhizomic" emergence of a social order reflected in the shifting dynamics of relative mana 'power/status' (Clastres 1977).

Lamenting the weakened state of Māori society in the mid-nineteenth century, Te Matorohanga, the tohunga whose teachings are collected in The Lore of the Whare-wananga (Smith 1913), put it this way:

Because tapu is the first thing, if there is no tapu all the actions of atua have no mana, and if the atua are lost everything is useless - people, their actions 
and their thoughts are in a whirl, and the land itself becomes broken and confused. (Smith 1913: 12)

Indeed, the neglect of relationships with atua, and the resulting transformation of the latter into malevolent atua kikokiko, constituted a profound transformation in the nature of both personhood and landscape such that an intimate correspondence between them was lost. Tamati Te Ito would certainly have agreed with Te Matorohanga that the land had become broken and confused, but he and the Kaingārara were more optimistic than the sage, believing that the restoration of a correspondence between people, atua and landscape was possible. In what follows I argue that through written correspondence with Te Ito, the Kaingārara sought to restore this ontological correspondence by attending closely to their tapu personhood and the ways they inhabited their tapu landscape.

\section{THE KAINGĀRARA LETTERS}

For some two years prior to his emergence as the inspired prophet of the Kaingārara movement in 1856, Tamati Te Ito had been travelling throughout Taranaki as the leader of an ope whakanoa 'tapu-removing troop'. This group of about 30 horsemen selected from all the tribes in Taranaki is thought to have visited most of the $p \bar{a}$ 'hill forts' in the district, removing stones into which the life force (mauri) of the pā had been instilled and thus protected, and driving away the atua kikokiko that guarded the stones (AJHR 1869 A-13: 15; Smith 1920: 50-51). When, in 1906, Percy Smith (Surveyor General, historian and founder of the Polynesian Society) asked Te Ito why he had removed the mauri stones he was told: "We wanted to combine all the Maori people from Mokau to Patea in one body, and remove the tapu from the old pas, as it was harmful to the people" (Smith 1920: 151). Mōkau and Pātea are at the northern and southern boundaries respectively of the Taranaki district.

The activities of the ope whakanoa went unrecorded by the settler press. However, by late 1856, Te Ito had assumed a more public identity in southern Taranaki as an inspired prophet (Riemenschneider 1857: 113), and by mid-1857 his activities were being featured in newspapers throughout the country (Lyttleton Times 1857; Otago Witness 1857; Wellington Independent 1857). In March 1857, the prophet initiated the final phase of what I have elsewhere termed "the Taranaki iconoclasm" (Sissons, forthcoming). Moving northwards up the coast from the southern boundary of Taranaki, the prophet orchestrated a sequence of spectacular whakanoa 'tapu removal' fires into which cartloads of soil, stones and vegetation from sacred groves were thrown along with tapu carvings and ancestral heirlooms (AJHR 1869 A-13: 15; Halse to McLean, 14 September 1857; Lyttleton Times, 8 and 15 August 1857; Nelson Examiner and NZ Chronicle, 23 January 1861, p. 3; Taylor 
journal, 28 March 1857). Te Ito's New Plymouth fire was held in June 1858 and was probably timed to coincide with the New Year (Puanga) marked by the rising of the star Rigel. From here he moved back down the coast, holding fire ceremonies at Oakura in September and Warea in October (Halse to McLean, 19 October 1857). Large numbers of people participated in the building of these fires and hundreds attended the final ceremonies - more than 600 people witnessed the Oakura fire (Halse to McLean, 14 September 1857).

Thus, Te Ito was not working alone. His ritual practice had wide public support, including that of many tribal leaders of Ngāti Ruanui, Ngā Ruahine, Taranaki Iwi and Te Āti Awa, all of whom, as Kaingārara, were fiercely opposed to any land sales (Sinclair 1969). Five days after Te Ito's Warea fire, some of the chiefs who had attended the ceremony wrote to the Government expressing their opposition to the Government's plans to purchase a large block of land - 40,000 acres - warning that many places within the block were tapu and guarded by atua, here termed "kaitiaki" 'guardian atua':

Ko nga kai tiaki o te wahi tapu, he ngarara, he weta, he pungawerewere, he taniwha, he mokonui.

The guardians of these tapu places are reptiles, wetas, spiders, water demons, and lizards. (AJHR 1861, C-No. 1: 218-19.)

The first surviving letter sent by a Kaingārara supporter to Tamati Te Ito also dates precisely from this time of heightened political tension over the ownership and guardianship of the land and its places of tapu - it is dated the day before Te Ito's Warea fire. This letter is included in the collection of 52 letters, written by Kaingārara to Te Ito between 1857 and 1863, and first identified and translated by Penelope Goode in her MA thesis (2001). In addition to providing initial translations of the often very obscure texts, Goode organised them chronologically and contextualised them with useful historical footnotes. These Kaingārara letters are a subset of 252 letters written by Māori to Māori that were plundered from two settlements in 1864 during the Taranaki land wars-Paiaka Māhoe Pā, on the Taranaki coast south of New Plymouth in April, and Mātaitawa, inland of New Plymouth, after it was occupied by colonial forces in October (Taranaki Herald, 23 April 1864 , p. $2 ; 15$ October 1864 , p. 3). Stuffed into sacks by soldiers, they were later passed on to Arthur Atkinson, editor of the Taranaki Herald and an enthusiastic militia volunteer, as potential sources of military intelligence. Colloquially (but also unfortunately) known as the "Atkinson Māori letters", they are now held in the Turnbull Library in Wellington, which has recently digitised them and made them openly available online (Paul Diamond, pers. comm., 2018). It is a rare privilege to have free access to these letters and, especially in light of the violence through which they have become available, we need to approach them and their authors with aroha 'compassion' and the utmost respect. 
The prophetic guidance sought and provided by Te Ito in the Kaingārara correspondence is termed "ritenga", a word that Goode usually translates as "ruling". Ritenga can also be glossed as 'ritual' or 'customary practice', but in this context, I think it is often better understood as 'inspired prescription' or 'inspired guidance'. In many cases, the inspired prescriptions were sought in order that people might dwell safely with each other and atua and to protect themselves from the malevolent influence of atua kikokiko. Te Ito himself was reported to have been inspired by a Waikato atua named Karutahi (Wellington Independent, 22 July 1857). Karutahi is today the name of a taniwha 'water guardian' that inhabits a swamp in Waikato (Keane 2007: 8). It is possible, therefore, that there is a connection between this taniwha and the prophet's atua, but the circumstances in which Te Ito came to be inspired by his atua are not recorded, and so any link must remain pure speculation.

More than a third of the Kaingārara letters (20 of 52) are requests for ritenga from Te Ito in relation to two domains of prophetic expertise previously associated with local tohunga: (i) mākutu 'sorcery' and (ii) the seasonal practices of fishing and agriculture. Most of the remaining letters are about the establishment of a Kaingārara settlement (8), records of Kaingārara court hearings (4) and requests for guidance in relation marital relations (5). In the discussion that follows, I interpret the ritenga letters that reference the domains of sorcery and seasonality and argue that they provide a window into localised engagements with atua and their tapu under the inspired guidance of a prophet whose words now travelled across streams, rivers and tribal boundaries.

The letters identified by Goode in her 2001 thesis have since been renumbered by the Turnbull Library; however, I have retained her numbers (included in brackets below) for ease of reference, especially given that her thesis is now readily available online. In most cases the translations below follow closely those suggested by Goode. Where I have proposed significant revisions I have indicated this in my text.

\section{Mākutu}

On 18 October 1857, Taituha, a Ngāti Ruanui chief from southern Taranaki, wrote to Te Ito at Te Whānga, Te Rangitāke's Te Āti Awa kāinga in northern Taranaki (letter 9). At the time of writing, Te Ito would have been away from home preparing for his last great fire to be held the following day at Warea:

To Tamati Ngamoke at Te Whanga pa

October 181857

Go, my loving letter to my son, Tamati Te Ito. Greetings to you. Great is my love for you. Hear this. The things you wrote about have been burnt in the fire. I burnt the shirt in the garden. As for the pipe, it was filled up with tobacco, and I put it inside the bag for you two to open. I heard perfectly well. I have filled that pipe and broken it. Greetings. That is all.

From me, Taituha 
Taituha was here informing Tamati Te Ito - whom he refers to in the original as his "tamaiti" 'child/son' because the prophet is of a younger generation than he - that he had followed Te Ito's ritenga: he had burned his shirt (and perhaps other items) in the garden and broken his pipe, which he had placed in a bag and sent with the letter to the prophet. The prophet had probably advised the destruction of the items mentioned because they had become tapu through an association with atua kikokiko and were thus causing Taituha to suffer in some way. Taituha may have been unable to attend Te Ito's October fire and so had, therefore, built his own small fire to destroy them. The way in which atua kikokiko had become associated with the items is unstated, but mākutu was probably suspected. Interestingly, Taituha wrote that he sent his pipe in a bag "for you two to open". The second person in this case was probably the paramount Te Āti Awa leader, Wiremu Kīngi Te Rangitāke, with whom Te Ito was living at the time and with whom he had become closely allied: another letter (25) is explicitly addressed to both men.

A related letter (223) reported a debate about how to deal with a tapu item referred to as a "mai", a general term for garment. There had been a disagreement over where the garment should be destroyed. One opinion was that it should be burned at a Te Āti Awa pā named Matarikoriko, but others said it would be wrong to burn it at the mouth of a stream there and that it should, instead, be returned south to its Ngāti Ruanui owners for them to destroy. Hapurona Pukerima wrote:

When Ruka arrived I came to fetch the garment [from him]. It is I, Hapurona, who will burn it.

Rapata said, "Where must it be burnt?"

Ruka said, "At Matarikoriko."

They said, "It is not right to burn it there at the mouth of Heringahaupapa." Ruka came back to me and said, "What I told you was wrong, Ha[purona]." They said it should be taken to Tihoi, to the people who own it. I sat quietly. My mouth did not speak.

The end.

From Hapurona Pukerimu.

Here, it appears than Te Ito was being asked for advice from a distance on a complex set of relationships, including between the tapu of the garment, which probably needed to be burnt because it had come under the influence of a malevolent atua, and the tapu of the pā and stream, guarded by other atua. Intertribal relations were also at stake. It appears that distinct tribal tapus from north and south were to be kept separate.

A third letter (23) in this domain refers to the use of cooking water (wai wera) to expel tapu in a context where there had been accusations of adultery. Tamati Reina, an influential chief of the southern Ngāti Ruanui tribe, wrote to Te Ito: 
I have written these words of mine to you for you to instruct me concerning both new and old errors. When the torch shines there is light. The sun is to guide the day and the moon is to guide the night. You, then, are to guide the hidden things of the heart. Who am I to know what is in my heart, or that of another man; is that sin of adultery mine? Show me whether it is someone else's, teach me so I may shortly know. That's all of these words. This is another word. The warm water was poured over my body. That man's work on me has stopped. It's all over.

I have argued in an earlier article (Sissons 2015) that prior to their baptism into the Christian faith, many chiefs throughout the country expelled their atua by pouring cooking water over their heads or touching parts of the body with cooked food, thus rendering themselves noa 'free from tapu'. In Taranaki, the whakanoa rites were performed by Wiremu Nëra, who, in the $1820 \mathrm{~s}$, had been taken as a slave to Northland where he subsequently converted to Christianity. Returning to Taranaki around 1837, Nēra preached widely and prepared people for baptism with ceremonies, termed "kokiro", during which warm water was, in a public ceremony, poured over people's heads from an iron cooking pot (Skevington letters, 19 April 1842; Rogers 1961: 464). In pouring water over himself, the southern chief had followed Te Ito's ritenga and similarly freed himself from the tapu influence of atua, now understood to be atua kikokiko. We do not know who "that man" was, but his "work" which had been "stopped" was probably sorcery.

Also in this domain is a letter (216) written to Te Ito by Te Ua Haumene, a Kaingārara adherent who would himself become inspired as a prophet, founding his own indigenous resistance movement, Pai Mārire, in 1862 (Head 1992: 9 n.15). Te Ua informed Te Ito that he had been unable to discover the cause of a person's emaciated condition, and he asked the prophet if he had completed his search for the appropriate ritenga. It is likely that this ritenga was a prescription to ward off sorcery since the emaciated condition would have suggested the presence of atua kikokiko. The name of the ill person is not provided in this undated letter, but he may have been Honeri, the son of Te Warihi, one of the Kaingārara leaders. In October 1858, Te Warihi wrote to Te Ito asking for help in discerning the cause of this son's illness (letter 31):

To Tamati Te Ito at Te Whanga

Tiw[a]rawara pa

Fifteenth day of October 1858.

Go my loving letter to my elder, Tamati Te Ito. Friend, Tamati, one of us, Honeri, is ill. He is really sick. What is the cause of the illness? You decide what to do.

Well, that's all.

From Te Warihi 
The following month Te Warihi wrote to Te Ito to say that his son had died and that he had been left completely bereft (letter 39).

Finally, we should add to this domain letter 74, which I quoted at the beginning of this article, written to Te Ito, Te Rangitāke and leaders of the Taranaki tribes by Rewi Maniapoto. In urging an end to the collective "mahi kikokiko" (the work of expelling atua kikokiko) of the Kaingārara movement, Maniapoto sought not only an end to Te Ito's counter-sorcery but also an end to the movement itself; he must have known that living with atua, including atua kikokiko associated with mākutu, was central to its mode of becoming.

\section{Fishing and Agriculture}

This domain of prophetic expertise includes 11 letters that sought advice about seasonal practices which had normally been orchestrated by local tohunga. The earliest of these letters (letter 12) is a report by Ropata Totoinumia, a Kaingārara leader, about a large gathering held at Waitaha, south of New Plymouth, at the beginning of Puanga, the Māori New Year, in June 1858. The rising of Rigel, which marked the start of the year, also signalled the beginning of the lamprey fishing season. Totoinumia reported that lamprey had been wrongly caught and eaten by several people within a tapu area marked by recently established council boundaries:

Next, I asked about the nature of the fault. Hemi Te Pua began the search by the stream at Waitaha ... they sought out the lamprey, which were roasted and eaten. Hemi saw them; he did not say they should be thrown away.

After that Hemi Te Pua looked for them. He had one fish, which was roasted and eaten.

After that Te Ranapia spoke of his getting bracken for a lamprey weir, but it was not made into a weir. After that he went down to the stream at Pungaereere. He caught two fish, which were roasted and eaten.

The guilty party publicly confessed their sins, but complained that the boundaries of the tapu areas had not been explained to them clearly enough, an excuse that the chief rejected. He asked them if they were willing to cease their transgressive behaviour and they agreed to do so. A second report on this new-year meeting (letter 13) describes in less detail the fishing transgressions but records more fully these confessions of guilt.

Totoinumia also reported to Te Ito (in letter 12) that he had clarified the northern and southern boundaries for line fishing and had warned people not to bring fish caught outside their district into their villages:

I said, "When someone wants to eat fish, he had better go to Te Namu. When he gets there, he eats fish and Te Takapu will be safe. When he returns to his 
home, he is not to bring fish to his village. Do not put to sea within these boundaries from Waiwiri from Otaha. Do not cast out a line; however, I will make an announcement so that all the people are aware of the stream, that is, all the streams, the mainland. The people of that place are stink-roaches, skinks, wetas, lizards; the older brother of these things is sorcery."

The chief's warning that sorcery is the "older brother" (tuakana) of stinkroaches, skinks, wetas and lizards echoed that given to the Government the previous year when Kaingārara leaders opposed the sale of a 40,000-acre block of land. As noted above, the Government was told that atua guarded sacred places within the block; now people were being reminded that these atua also guarded their mainland streams. In such a dangerous context, respect for the boundaries established by the Kaingārara council was vital for safe habitation.

It had always been the responsibility of tohunga to define fishing boundaries and to mark these with rocks (on which designs, often spirals, were painted) or stakes to signal ownership of the ground and that the area was under the protection of an atua (Best 1924, vol. 2: 400-401). Te Ito had now assumed oversight of this role; however, people appear to have been having difficulty reconciling his inspired ritenga with local convention. Thus, one local chief wrote to the prophet complaining about the prophet's numerous prescriptions (ritenga mahamaha) of which he and his community had had no previous knowledge. All they had known previously, he claimed, was that fishing canoes needed to stay within certain boundaries (letter 14). And the distance between Te Ito and his Kaingārara followers became a significant issue when advice on fishing was needed quickly. In letter 48, one of Te Ito's judges asked Te Ito to clarify a ritenga that appears to have prohibited fishing for kahawai. Here, a rapid reply from Te Ito would have been hoped for:

To Tamati Te Ito Ngamoke at Te Wanga pa Waitara

Te Hauwai pa Waitaha

December 211858

Go, my letter, to my elder, Tamati Te Ito Ngamoke. Old friend, greetings to you. This is [about] a ritenga which I have received. The people of War[e]a said some "children" [i.e., the Kaingārara] should paddle about, trawling for kahawai, because they saw the kahawai at high tide. They looked to us to say if they should go out paddling. I am seeking advice on this because it is not clear to me, hence I have written my letter to you. Will you clarify that ritenga for me. Well, that's all.

From Te Watarauihi, Judge

(My revised translation) 
There are six letters in the collection requesting ritenga in relation to the construction and launching of fishing canoes. Again, this was an activity in which the tohunga had always played a significant role, directing the "consecrated industry" of construction (Handy 1927: 282) and determining the time and place of launching, placing the activities under the protection of atua. The earliest of the six letters (letter 39), written in November 1858, informed Te Ito that a new canoe for the southern Ngāti Ruanui was planned, but that construction would only proceed if the project had his blessing. This must have been forthcoming because two weeks later the same writer told Te Ito that the construction work had been completed and he requested a ritenga for the launch (letter 42).

The following month, in December 1858, the prophet was informed that a canoe named Maru - after the Ngāti Ruanui atua brought to New Zealand on the ancestral Aotea canoe-had been launched (letter 217; Sole 2005: 24). However, there had been significant disagreement about the correct place from which to do this:

To Tamati Te Ito Ngamoke at Te Wanga pa

Keteonetea pa

December 19 th of the [days] 1858

Go, my letter, to Tamati. Friend, it was on Friday I arrived. By the time I arrived the canoe had been taken to Ohawe. When I arrived it was discussed with me and I was told that the canoe should be dragged to Waihi. Panapa was dark about their dragging of the canoe to Ohawe. They said it should be dragged to Waihi. Instead, Maru was brought to Waihi. If you disagree, please write to me at once ...

From me, Te Kepa

Soon after, Maru was smashed at sea, no doubt vindicating the opinions of some leaders who thought that it had been launched in the wrong place. In a letter written on 27 December 1858 (letter 49), Te Ito was told of the loss, but the writer urged him not to be depressed or dark-hearted (pōuri) because they had already cut down a tree for a new canoe. The local leaders had independently determined that the correct course of action would be to destroy the fish that had been caught from the broken canoe. The fish were probably considered tapu because they had come under the influence of the atua that had been responsible for the destruction of the canoe. Two successful fishing trips had resulted in catches of tuna and 80 dogfish (mangō), all of which were burned in a fire. The atua involved here was possibly Maru or one associated with Maru, after whom the canoe was named; a few years earlier, and in the same general locality, Te Ito had destroyed a stone image of Maru by throwing it into one of his fires (Sissons, forthcoming; Smith 1908: 143). 
In addition to letters seeking advice on fishing, this seasonal domain includes a letter written in October, the month for planting potatoes, informing the prophet that the Kaingarara leaders had acted in accordance with his guidance and that their potato rite had been completed (letter 35):

To Tamati Te Ito Ngamoke at Te Whanga pa Waitara

Te Hauwai pa Waitaha

October 251858 .

Go our loving letter to our elder. Old friend, greetings to you and your children. We have received your letter and recognise that your word is right. Listen here, it was not us, it was the people who lived there who kept asking us all the time and therefore we agreed to what they said about that food. Later we pounded [those potatoes], and the potato ritenga was completed. However, we used up all the firewood. Those [uncooked?] potatoes are just lying about. In our opinion, those potatoes should just be left in the pit to rot away. That's all of this ...

Well, that's all.

from Ihaia Te Karewa

(My revised translation)

It is unclear what the purpose of this rite was or why it had involved the building of a large fire. However, in the early 1850 s, some six years before Te Ito's spectacular whakanoa fires, many communities had gathered around fires built in sacred groves upon which potatoes were cooked. These were eaten by the assembled villagers in order to drive away the atua kikokiko that inhabited the groves in the form of lizards (Sissons 2016). Perhaps some potatoes had been used in a similar rite in preparation for planting.

\section{DISCUSSION}

I have argued elsewhere (Sissons 2013, 2015) that hapū 'sub-tribal kingroups' can be usefully reconceptualised in Deleuzian terms as assemblages that territorialised people, atua and features of the landscape around intensely tapu centres - chiefs, tohunga and meeting houses. From this perspective, Kaingārara might be viewed as a reterritorialisation of multiple Taranaki hapū around a new intense centre - the prophet, Te Ito. However, in his recent call for a "one-world anthropology" Tim Ingold has rightly criticised the often overly static uses of the assemblage concept and has proposed, instead, that we employ the concept of "correspondence" to capture the sense of lives "lived-with" rather than lives as "components of" something bigger:

Thus, in place of assemblage as a way of talking about the multiplicity of soul-life, as if it were an alliance of souls, I propose the term correspondence 
to connote their affiliation. "Life as a whole", then, is not the articulatory summation but the differential correspondence of its particulars. (Ingold 2018: 160)

Understanding Kaingārara through a lens of correspondence certainly highlights its distinctiveness as a mode of becoming. If, in Ingold's Deleuzian anthropology, the universal is "a plane of immanence from which difference is ever-emergent" (p. 165), then the particularity of the Kaingārara was, in large part, that it was a mode of political life "lived with" atua, one emerging through a correspondence about and correspondence with atua and their tapu. Moreover, the engagement of Kaingārara with atua and their tapu can also usefully be considered a "task" in Ingold's sense, as "something that falls to us, as responsive and responsible beings, as part of the life we undergo" (p. 166). The task of engaging with atua was, indeed, part of the life-condition in which Kaingārara found themselves after conversion to Christianity.

At the intense centre of Kaingārara correspondence - understood as both writing and becoming - was Te Ito. His becoming-prophet was also the becoming-Kaingārara of the movement's members, and in the case of the fires, it was also the becoming-noa of persons, places and things that had been under the influence of atua. Tapu, for Kaingārara, was not a transcendent order that was distinct from or imposed upon social life. It was a condition in which people found themselves, the inspired knowledge of which was shared by a prophet whose own becoming unfolded in correspondence with the lives that he guided from a distance.

But "life as a whole" needs to be understood as both differential correspondence and differential non-correspondence. The difficulty with Ingold's view is that when life is treated as nothing but correspondence-as one enormous "meshwork" - then the differentiation of meshworks from each other-which Deleuze and Guattari understood as the reterritorialising of assemblages - is left unaccounted for. For this reason, I wish to retain the concept of "intense centre" to denote the person, place or thing around which correspondence is territorialised. In my view, modes of correspondence are differentiated from each other in terms of the intense centres around which they form or emerge. Rather than view social life as a decentred meshwork within one world of continuous emergence, we might better understand it as the emergence of multiple meshworks of differentially centred correspondence.

Deleuze and Guattari explain the concept of intense centre with reference to their allegory of territorialisation:

There is always a place, a tree or grove, in the territory where all the forces come together in a hand-to-hand combat of energies.... This intense center is simultaneously inside the territory, and outside several territories that converge 
on it .... Inside or out, the territory is linked to this intense center ... where everything is decided. (Deleuze and Guattari 1987: 321)

Te Ito represented such a convergence of forces. Inspired by an atua, and through engagement with other atua, including atua kikokiko, he was both the intense centre of the Kaingārara and the point of convergence of hapū (and their distinct territories) where everything in relation to tapu was decided.

$$
* * *
$$

The Kaingārara letters were sent to Te Ito from 16 settlements located throughout the Taranaki district by members of all the main tribes: Te Âti Awa, Taranaki Iwi, Ngā Ruahine and Ngāti Ruanui in the south. Each of these tribes comprised a number of hapu that were territorialised around leaders of high mana. The written correspondence shows that in discerning breaches of tapu and prescribing ritenga to deal with these, Te Ito was essentially performing the same service for multiple hapu across Taranaki as had been performed by pre-Christian tohunga for their particular hapū (Shortland 1856: 121). However, now this work (mahi) was understood to be "mahi kikokiko", and it had become focused on two domains within which potentially malevolent atua and their tapu were considered most active: sorcery and seasonal work. These were domains of local struggle in which the continuity of life was most at risk through a non-correspondence that arose from malign intent or from a failure to respect the guardians of land, waterways and sea. In joining with Kaingārara in their life-struggles, albeit from a distance, Te Ito was restoring a correspondence between people and place and, in the process, contributing to the creation of a new, politically independent mode of dwelling.

In his capacity as the intense centre of a political movement for life, Te Ito was not unlike one of Hocart's kings. Hocart wrote that the king primarily serves a ritual rather than an administrative purpose: "He is the repository of the gods, that is, of the life of the group" (Hocart 1970: 98-99). Te Ito was both, but he was not a king, nor was his chief, Wiremu Kingi Te Rangitāke, although the latter may have aspired to such a status. In any case, Rewi Maniapoto of Waikato was taking no chances. Hence his demand that Te Ito and his supporters cease their efforts to unite Taranaki through their engagements with atua. Te Ito did, in fact, cease his correspondence with the Kaingārara some three months later-but not because he had obediently heeded Maniapoto's command. Rather, it was because government troops had burned down his village, forcing him and Te Rangitāke to flee inland with their people. The Kaingārara movement never recovered. 


\section{ACKNOWLEDGEMENTS}

I want to particularly thank Dr. Dennis Ngawhare for his wise and knowledgeable advice concerning the tribal history and tribal landscape of Taranaki. Our ongoing discussions, as we work together on a book about Te Ito, have greatly deepened my understanding of the origins of prophetic movements in Taranaki. I have also gained significant insights through kōrero 'discussions' about Te Ito at Parihaka, epsecially with Dr. Ruakere Hond and Te Whiti o Rongomai. The research for this article was made possible by a three-year grant from the Marsden Fund.

\section{REFERENCES}

AJHR, 1860, 1861, 1869. Appendices to the Journals of the House of Representatives. Best, Elsdon, 1924. The Maori. 2 vols. Wellington: Government Printer.

Clastres, Pierre, 1977. Society Against the State. New York: Urizen Books.

Deleuze, Gilles and Félix Guattari, 1987. A Thousand Plateaus: Capitalism and Schizophrenia. Translated by Brian Massumi. Minneapolis: University of Minnesota Press.

Goldie, William H., 1904. Maori medical lore: Notes on the causes of disease and treatment of the sick among the Maori people of New Zealand, as believed and practised in former times, together with some account of various ancient rites connected with the same. Transactions of the New Zealand Institute 37: 1-120.

Goode, Penelope, 2001. The Kaingarara Letters: The Correspondence of Tamati Te Ito Ngamoke in the A.S. Atkinson Papers, 1857-1863. MA thesis, University of Canterbury, Christchurch. https://ir.canterbury.ac.nz/handle/10092/4313

Halse to McLean, 1857 (14 September and 19 October). The Papers of Sir Donald McLean, Inward Letters. Alexander Turnbull Library, Wellington.

Handy, E.S. Craighill, 1927. Polynesian Religion. Bernice P. Bishop Museum Bulletin 34. Honolulu.

Hanson, F.A. and L. Hanson, 1983. Counterpoint in Maori Culture. London: Routledge and Kegan Paul.

Head, Lyndsay, 1992. The gospel of Te Ua Haumene. Journal of the Polynesian Society 101 (1): 7-44.

Hocart, Arthur, 1970. Kings and Councillors: An Essay in the Comparative Anatomy of Human Society. Chicago: University of Chicago Press.

Ingold, Tim, 2018. One world anthropology. HAU: Journal of Ethnographic Theory 8 (1-2): 158-71 (Special Section: Toward a New Humanism).

Keane, Basil, 2007. Taniwha: Taniwha today. Te Ara: The Encyclopedia of New Zealand. https://teara.govt.nz/en/taniwha/page-8

Nicholas, John Liddiard, 1817. Narrative of a Voyage to New Zealand. 2 vols. London: James Black and Son.

Prytz-Johansen, Jørgen, 1954. The Maori and His Religion in Its Non-ritualistic Aspects. Copenhagen: Ejnar Munksgaard.

Riemenschneider, J., 1857, 1858. Reports for June 1857 and July 1858. In Riemenschneider Papers (typescript), vol. VI, Pukeariki Museum, New Plymouth. 
Rogers, Lawrence M. (ed.), 1961. The Early Journals of Henry Williams: New Zealand 1826-40. Christchurch: Pegasus Press.

Salmond, Anne, 1989. Tribal words, tribal worlds: The translatability of tapu and mana. In M. Marshall and J.L. Caughy (eds), Culture, Kin and Cognition in Oceania: Essays in Honor of Ward H. Goodenough. Washington, DC: American Anthropological Association, pp. 55-78.

Scholefield, Guy H. (ed.), 1960. The Richmond-Atkinson Papers. Vol. 2. Wellington: Government Printer.

Shortland, Edward, 1856. Traditions and Superstitions of the New Zealanders. London: Longman, Brown, Green, Longmans \& Roberts.

Sinclair, Keith, 1969. Te Tikanga Pakeke: The Maori anti-land-selling movement in Taranaki, 1849-59. In Peter Munz (ed.), The Feel of Truth: Essays in New Zealand and Pacific History. Wellington: A.H. \& A.W. Reed, pp. 77-92.

Sissons, Jeffrey, 2013. Reterritorialising kinship: The Māori hapū. Journal of the Polynesian Society 122 (4): 373-91.

2015. Personhood as history: Māori conversion in light of the Polynesian iconoclasm. Journal of the Polynesian Society 124 (2): 129-46.

2016. Dangerous remains: Towards a history of tapu. Sites: A Journal of Social Anthropology and Cultural Studies 13 (2): 49-65.

- forthcoming. The Taranaki iconoclasm. Special Issue, Religious Rupture and Revival in the Pacific, edited by Fraser Macdonald and Michael Goldsmith. Journal of the Polynesian Society 128 (4).

Skevington, John, 1842-43. Letters to the Secretaries. John Kinder Theological Library, Auckland.

Smith, S. Percy, 1908. History and traditions of the Taranaki Coast: Chapter IX. Journal of the Polynesian Society 17 (67): 111-48.

-1913. The Lore of the Whare-wananga, or, Teachings of the Maori College on Religion, Cosmogeny and History. Memoirs of the Polynesian Society, vol. III. 1920. Clairvoyance among the Maoris. Journal of the Polynesian Society 29 (3): 149-61.

Sole, Tony, 2005. Ngati Ruanui: A History. Wellington: Huia.

Taylor, Richard, 1856-59. Journals (typescript), volume 10. Alexander Turnbull Library, Wellington.

-1855. Te Ika a Maui, or New Zealand and Its Inhabitants. London: Wertheim and Macintosh.

Whiteley to McLean, 1858 (25 March). The Papers of Sir Donal McLean, Inward Letters. Alexander Turnbull Library, Wellington.

\section{AUTHOR CONTACT DETAILS}

Jeffrey Sissons, School of Social and Cultural Studies, Victoria University of Wellington, PO Box 600, Wellington, New Zealand. Email: jeff.sissons@vuw.ac.nz 
